Dostępne online www.journals.wco.pl/los

Zeszyty Naukowe WCO, Letters in Oncology Science 2020;17(1):22-28

CrossMark
Letters in Oneology Science

ISSN 2543-6724

ZESZYTY NAUKOWE WIELKOPOLSKIEGO CENTRUM ONKOLOGII

Praca poglądowa/Review paper

\title{
Leczenie napromienianiem raka stercza na podstawie doniesień z Konferencji Amerykańskiego Towarzystwa Radioterapii Onkologicznej (ASTRO), San Francisco 2014 oraz Europejskiego Towarzystwa Radioterapii Onkologicznej (ESTRO ), Turyn 2015
}

\section{Radiotherapy treatment for prostate cancer based on presentations from the American Society on Therapeutic Radiation Oncology (ASTRO), San Francisco 2014 and the European Society on Radiation Oncology (ESTRO), Turino 2015}

\section{Piotr Milecki ${ }^{1,2}$}

\begin{abstract}
${ }^{1}$ Oddział Radioterapii Onkologicznej I z Izba Przyjęć, Zakład Radioterapii I z Izba Przyjęć, Wielkopolskie Centrum Onkologï w Poznaniu,
\end{abstract} ${ }^{2}$ Katedra i Zakład Elektroradiologii Uniwersytet Medyczny im. Karola Marcinkowskiego w Poznaniu

\begin{abstract}
Streszczenie
Rak stercza należy do najczęściej diagnozowanych nowotworów złośliwych u mężczyzn w krajach rozwiniętych. $\mathrm{Z}$ tego też powodu optymalne leczenie chorych z tym nowotworem jest szczególnym wyzwaniem dla lekarzy onkologów radioterapeutów, urologów i onkologów klinicznych. W związku z tym podczas konferencji naukowych ASTRO i ESTRO dużo uwagi poświęcono właśnie temu nowotworowi. Ostatnio przeprowadzone badania kliniczne wskazują, że zastosowanie terapii hormonalnej w skojarzeniu z nowoczesnym napromienianiem, poza bardzo pożądanym efektem jakim jest poprawa przeżyć chorych w grupie chorych o pośrednim i wysokim ryzyku progresji, może przyczynić się do zmniejszenia powikłań popromiennych. W trakcie konferencji przedstawiono takže wyniki badań klinicznych, które potwierdzają zysk w wyniku zastosowania eskalacji dawki w radioterapii. Niemniej zysk w efekcie kontroli biochemicznej wymaga długiego czasu przeżycia chorych aby przełożył się na zysk w przeżyciach całkowitych lub swoistych dla raka stercza.
\end{abstract}

Adres do korespondencji

Piotr Milecki

Oddział Radioterapii Onkologicznej I z Izbą Przyjęć, Zakład Radioterapii I z Izbą Przyjęć

Wielkopolskie Centrum Onkologii, ul. Garbary 15, 61-866 Poznań, Polska

Telefon. $+48618850-878$

e-mail: piotr.milecki@wco.pl 


\begin{abstract}
Prostate cancer is one of the most frequent diagnosed cancer in men in devoloped countries. So, the crucial point for achiving the best results of therapy is chosing optimal treatment for particular patient. The appriopriate treatment decision process is challenging for all specialists involved in this process such as urologists, radiation oncologists, and clinical oncologists. Prostate cancer treatment with radiotherapy during the scientific conferences such as ASTRO and ESTRO was one of significant part of scientific disscusion regarding reults of the most important clinical studies evaluated the role of radiotherapy. One of the most important conclusion from recently presented trials for intermediate and high-risk prostate cancer patients stated that combined treatment encompassed androgen deprivation therapy and modern high-dose radiotherapy gives the best results in comparison to high-dose or moderate dose radiotherapy alone. Another very important groups of trials concerned the role of dose escalation for patients with prostate cancer and all studies clearly showed that dose escalation is related with significant clinical benefit, but still it is some concerns regarding translation of biochemical gain into overal survival benefit especially when the follow-up period is relatively short.
\end{abstract}

Stowa kluczowe: Rak gruczołu krokowego, radioterapia, terapia hormonalna

Key words: prostate cancer, radiotherapy, hormonal therapy

\title{
Wstęp
}

Prognozy dotyczące liczby zachorowań na nowotwory złośliwe wskazują, że w Polsce w następnym dziesięcioleciu odnotujemy znaczący wzrost diagnozowanych chorych z rakiem stercza [1,2].Ztego też względu poszukiwanie poprawy wyników leczenia z udziałem radioterapii, która jest jedną z głównych metod leczenia tego nowotworu jest bardzo istotną kwestią jakiej poświęcono w znacznej mierze czas w trakcie konferencji ASTRO 2014 i ESTRO 2015. Wprowadzenie nowoczesnej radioterapii które miało miejscew ostatnich dekadach znacząco przyczyniło się do poprawy wyników leczenia raka stercza przy zastosowaniu tej metody [3,4,5]. Niemniej obecność gruczołu krokowego w pobliżu pęcherza moczowego oraz odbytnicy znacząco ogranicza możliwość eskalacji dawki. Jednym z najważniejszych celów radioterapii jest obniżenie dawki właśnie w tych narządach krytycznych, co w naturalny sposób prowadzi do ograniczenia powikłań popromiennych. Między innymi zmniejszenie objętości gruczołu krokowego skutkuje zmniejszeniem napromienianej objętości, a to powinno przełożyć się na zmniejszenie objętości napromienianych tkanek zdrowych i w ten sposób poprawić wyniki poprzez zmniejszenia objawów ubocznych. Ostatnio przeprowadzone badania kliniczne wskazują, że zastosowanie neoadjuwantowej terapii hormonalnej przed rozpoczęciem napromieniania, poza bardzo pożądanym efektem jakim jest poprawa przeżyć chorych w grupie chorych o pośrednim i wysokim ryzyku progresji, przyczynia się także do zmniejszenia powikłań popromiennych. Powyższe znalazło swoje uzasadnienie w zaleceniach kluczowych towarzystw naukowych.

W Polsce liczba nowych zachorowań na RS nadal rośnie, a prognozy epidemiologiczne wskazują, że w okresie najbliższych 10 lat może ona ulec podwojeniu. W związku z tym należy założyć, że grupa chorych u których zostanie zdiagnozowany nowotwór w miejscowo zaawansowanym stadium choroby nowotworowej będzie nadal istotna liczebnie pomimo odnotowanego trendu diagnozowania chorych we wcześniejszym stadium klinicznym choroby [1].

Przełomowym w leczeniu RS było między innymi wprowadzenie nowoczesnych technik napromieniania do których należą konformalna radioterapia trójwymiarowa oraz radioterapia wykorzystująca wiązkę intensywnie modulowaną (IMRT). Ponadto ostatnio do praktyki klinicznej weszła kolejna jej modyfikacja, a mianowicie RT sterowana obrazem ( Image Guided Radiotherapy - IGRT). IGRT w połaczeniu z IMRT stanowią obecnie złoty standard współczesnej radioterapii RS z tego względu, że umożliwią precyzyjne dostarczenie dawki w obręb napromienianego stercza, pęcherzyków nasiennych, czy węzłów chłonnych, a równocześnie ograniczają dawkę w narządach krytycznych. Generalnie nowczesne techniki RT pozwalają 
zmniejszyć napromienianą objętość tkanek zdrowych, które są reprezentowane przez tzw. krytyczne narządy zdrowe (organs at risk). Przekłada się w oczywisty sposób na zmniejszenie negatywnego wpływu napromieniania. Spowodowane jest to tym, że poza wysokością dawki promieniowania jakie otrzymuje tkanka zdrowa na biologiczny efekt promieniowania ma bardzo duży wpływ również objętość w jakiej dochodzi do deponowania wspomnianej dawki. Podjęcie wysiłku w kierunku zmniejszenia tej objętości jest jednym z priorytetów współczesnej RT [6-8]. Między innymi w przypadku RT RS wykazano, że zmniejszenie napromienianej objętości narządów zdrowych (pęcherz moczowy i odbytnica) pozwala ograniczyć ryzyko wystąpienia powikłań popromiennych otwierając w ten sposób możliwość eskalacji dawki w guzie nowotworowym. Należy zaznaczyć, że fundamentalna zasada RT nie uległa zmianie od początku jej wprowadzenia do leczenia nowotworów złośliwych. Najogólniej sprowadza się ona do takiego przygotowania planu leczenia i jego realizacji, aby dostarczyć jak największą dawkę w objętość guza nowotworowego przy jak najmniejszym, akceptowalnym ryzyku powikłań.

W trakcie Konferencji ASTRO 2014 problemom nowotworów urologicznych poświęcono 2 wystąpienia ustne w sesji plenarnej i $5 \mathrm{w}$ sesjach edukacyjnych, 1 panel naukowy dotyczący jakości życia chorych po leczeniu oraz 4 sesje naukowe. Sesje plenarne pozostają najważniejszymi spośród wszystkich naukowych wydarzeń na konferencji w trakcie których przedstawione zostają najbardziej doniosłe wyniki badań naukowych z którymi powinna zostać zaznajomiona jak największa grupa uczestników konferencji. W pierwszej prezentacji zespół badaczy z Hiszpani pod kierownictwem Zapatero przedstawił wyniki randomizowanego badania klinicznegi 3 fazy DART 01/05 [9]. W badaniu powyższym dokonano porównania wyników leczenia u chorych z RS w grupie chorych wysokiego i pośredniego ryzyka progresji nowotworu z zastosowaniem RT w przypadku skojarzenia z leczeniem hormonalnym. Przesłanki jakie skłoniły badaczy do rozpoczęcia tego badania to między innymi wyniki szeregu badań klinicznych, które wykazały, że leczenie skojarzone obejmujące terapię hormonalną i RT stosowaną w standardowej dawce pozwala uzyskać istotny zysk w przeżyciach całkowitych oraz przeżyciach swoistych dla RS w stosunku do samodzielnej RT [10-14]. Kolejną przesłanką do rozpoczęcia tego badania było szereg wyników przeprowadzonych dotychczas badań kliniczncyh, które wskazały na możliwość uzyskania zysku w przypadku zastosowania eskalacji dawki w RS. Powyższe dwa aspekty brane łącznie skłoniły badaczy do zadania pytania o potrzebę prowadzenia długoczasowej hormonoterapii w sytuacji kiedy stosujemy wysoką dawkę w RT. Główne cele badawcze zostały sformułowane jak poniżej: czy długotrwała hormonoterapia ma przewagę nad krótkotrwałą w przypadku zastosowania wysokiej dawki RT, a głównymi punktami końcowymi badania były czas przeżycia bez wznowy biochemicznej określany według kryterium Phoenix oraz objawy uboczne jakie towarzyszą takiemu leczeniu skojarzonemu. Z pozostałych punktów końcowych (drugoplanowych) badacze wymienili przeżycie całkowite, przeżycie swoiste dla RS oraz przeżycie wolne od przerzutów odległych. Do badania zakwalifikowano 364 chorych z potwierdzonym RS których poddano randomizacji w okresie od 2005 do 2010 roku do ramienia w którym stosowano hormonoterapię jedynie przez 4 miesiące przed rozpoczęciem RT (neoadjuwantowo) oraz ramienia w którym hromonoterapię kontynuowano przez dalsze 24 miesiące już po zakończeniu napromieniania. W obu ramionach stosowano dawkę w radioterapii nie mniejszą niż 76 Gy. Wyniki badania wskazują na to, że największy zysk z zastosowania długotrwałej hormonoterapii odnoszą chorzy z grupy wysokiego ryzyka progresji (cT3 lub PSA> 20 ng/ml lub Gleason > 7). W odniesieniu do wszystkich punktów końcowych w tej podgrupie chorych odnotowano istotną statystycznie poprawę wyników leczenia z zastosowania długotrwałej hormonoterapii pomimo zaaplikowania wysokiej dawki z RT. Natomiast w grupie o pośrednim ryzyku progresji RS nie odnotowano istotnego zysku wynikającego z zastosowania długotrwałej hormonoterapii. Autorzy badania nie odnotowali jakiegokolwiek wpływu negatywnego dłuższego leczenia hormonalnego na poziom toksyczności ze strony dolnego odcinka przewodu pokarmowego czy układu moczowego. Spośród ograniczeń badania należy wymienić relatywnie krótki czas obserwacji, małą liczbę zdarzeń oraz brak ramienia badawczego z wysoką dawką w RT ale bez jakiejkolwiek interwencji hormonalnej. Niewątpliwie na sukces współczesnej RT w leczeniu RS o pośrednim i wysokim ryzyku progresji ma wpływ jej skojarzenie z terapią hormonalną. Idea skojarzonego leczenia obejmująca leczenie hormonalne rozumianego jako depresja produkcji testosteronu (ang. Androgen Deprivation Therapy - ADT) i RT została zaczerpnięta z doświadczeń jakie zebrano w wyniku stosowania terapii hormonalnej $\mathrm{w}$ połączeniu z radykalną prostatektomią. Wstępne wyniki zastosowania neoadjuwantowej ADT przed 
zabiegiem operacyjnym wskazywały na możliwość obniżenia stopnia zaawansowania klinicznego w zakresie narządowego i idące za tym zmniejszenie objętości guza nowotworowego (ang. downstaging and downsizing). Niestety wyniki przeprowadzonych randomizowanych kontrolnych badaniach klinicznych nie potwierdziły wydłużenia przeżyć całkowitych u chorych leczonych w sposób skojarzony (przedoperacyjna ADT + RP) $\mathrm{w}$ stosunku do samodzielnej prostatektomii. Doświadczenia powyższe stworzyły jednak podwaliny koncepcyjne badań nad oceną efektywności leczenia skojarzonego, w których metodą podstawową została RT. ADT zastosowana przed RT prowadzi do zmniejszenia objętości części nienowotworowej gruczołu krokowego jak również, albo przede wszystkim guza nowotworowego. Stwarza to warunki do napromieniania mniejszych objętości zdrowych narządów bedących w sąsiedztwie stercza, co może prowadzić do obniżenia dawki w narządach krytycznych (pęcherz moczowy, odbytnica). Średnie zmniejszenie objętości gruczołu krokowego w trakcie trwającej od 3 do 6 miesięcy ADT według różnych ocen wynosi od 20\% do 50\% jej pierwotnej objętości [4]. Zmniejszenie objętości stercza uzyskane w wyniku zastosowania przekraczającej ponad 4 miesiące ADT jest już niewielkie (7\%) i z punktu widzenia dawek jakie otrzymują narządy krytyczne mało znaczące. $Z$ drugiej strony, zbyt wczesne rozpoczęcie napromieniania, np. wraz z zastosowaniem N-ADT może paradoksalnie prowadzić do zwiększenia toksyczności leczenia. Wynika to z możliwości „pociągania” odbytnicy przez zmniejszający się gruczoł krokowy w objętość wysokiej dawki promieniowania, przy jednoczesnym ryzyku „ucieczki” guza nowotworowego, zwłaszcza w sytuacji braku stosowania IGRT. Należy podkreślić, że jednak największy zysk terapeutyczny związany ze stosowaniem ADT w skojarzeniu z RT wynika z tego, że leczenie hormonalne prowadzi do zmniejszenia liczby komórek guza stercza. Stwarza to większe szanse na zniszczenie pozostałych komórek nowotworowych w wyniku napromieniania. Rozpoczęta przed napromienianiem, a dalej stosowana w jej trakcie ADT zmniejsza liczbę komórek w obrębie guza nowotworowego. Skutkuje to poprawą utlenowania pozostałych komórek nowotworowych obecnych w guzie nowotworowym. Między innymi ostatnio przeprowadzone badania wskazują, że ADT prowadzi do obniżenia hipoksji w komórkach nowotworowych stecza [6]. Ponadto zauważano, że ADT obniża ekspresję mRNA VEGF komórek raka stercza, co może ograniczać patologiczną angiogenezę sprzyjającą rozwojowi raka. Należy w tym miejscu podkreślić, że hipoksja jest jednym z istotnych czynników zwiększającym oporność komórek nowotworowych na napromienianie. Ponadto, guz nowotworowy w środowisku niedotlenienia jest bardziej podatny na utworzenie przerzutów odległych. Należy ponadto zaznaczyć, że ADT prowadzi do śmierci komórek na drodze apoptozy niezależnie od działania promieniowania jonizującego. $\mathrm{Z}$ tego też względu ADT może eliminować komórki nowotworowe, które mogą być oporne na napromienianie. Leczenie skojarzone może prowadzić do komplementarności działania obu form terapii. Wskazano w oparciu o model doświadczalny na możliwość uzyskania efektu addytywnego lub nawet supraadytywnego w przypadku kiedy ADT wyprzedza napromienianie przynajmniej na 3 dni. Ponieważ jedną z głównych przyczyn niepowodzenia w leczeniu zaawansowanego RS są mikroprzerzuty, to właśnie neoadjuwantowa i adjuwantowa ADT jako formy terapii systemowej mogą poprawiać wyniki leczenia również i w tym względzie.

Jak już wcześniej wspomniano jednym z celów ADT aplikowanej przed rozpoczęciem napromieniania jest zmniejszenie ryzyka powikłań popromiennych w ważnych narządach krytycznych. Zastosowanie 3-miesięcznej neoadjuwantowej ADT zmniejsza intensywność powikłań ze strony odbytnicy, niemniej wydłużenie czasu ADT do 6 miesięcy przed rozpoczęciem napromieniania nie zwiększa już tego efektu [15].

Niezwykle ważnym celem obok wyleczenia chorego z RS jest maksymalne ograniczenie objawów ubocznych [16]. W związku z tym zalecenia NICE ( National Institute for Health and Care Excellence) opublikowane w styczniu 2014 roku wprowadzają dodatkowe wskazania dla agonistów LHRH: terapięneoadjuwantowąprzed RT w grupie chorych charakteryzujących sie wysokim ryzykiem progresji RS. Mianowicie wytyczne zalecają stosowanie hormonoterapii przed rozpoczęciem RT, co powinno przełożyć się na zmniejszenie powikłań popromiennych. W powyższych zaleceniach powołano się między innymi na wyniki badań przeprowadzone przez zespół Sampera i współpracowników oraz Ozyigit i współpracowników [17,18]. Samper dokonał analizy rozkładu dawki w najważniejszych narządach krytycznych w RT RS. Dokonana analiza 28 planów leczenia chorych z RS wykazała, że zastosowanie neoadjuwantowej hormonoterapii powoduje znaczące ograniczenie dawki promieniowania w odbytnicy i pęcherzu moczowym. Autorzy odnotowali po okrseie 2 miesięcznej terapii hormonalnej istotnie statystycznie zmniejszenie się objętości gruczołu krokowego. W kolejnym etapie 
analizy odpowiedzieli na pytanie w jaki sposób zmiana objętości gruczołu krokowego może przełożyć się na wysokość dawki w najważniejszych narządach krytycznych, czyli odbytnicy i pęcherzu moczowym. Jednym z istotnych parametrów oceny jakości planu leczenia napromienianiem jest objętość odbytnicy i pęcherza moczowego, która otrzyma w procesie leczenia większą dawkę aniżeli 60 Gy (parametr V6o). Samper i współautorzy wykazali, że V6o uległ istotnemu zmniejszeniu w obu narządach krytycznych. Podobnej analizy dokonał Ozyigit i współautorzy, którzy również zastosowali analog LHRH (triptorelin) i również w tym przypadku odnotowali istotne zmniejszenie się dawek w obu krytycznych narządach zdrowych.

Podsumowując, ostatnie doniesienie z konferencji ASTRO wskazuje na celowość stosowania leczenia skojarzonego, co ma szczególne znaczenie w przypadku stosowania nawet wysokiej dawki radioterapii stanowiącej standard.

Drugie niezwykle ważne dosniesienie przedstawione podczas sesji plenarnej konferencji dotyczyło badania randomizowanego 3 fazy RTOG 0126 porónującego wyniki leczenia w grupie chorych o pośrednim ryzyku progresji w przypadku zastosowania wysokiej (79,2 Gy) lub standardowej dawki promieniowania (70,2 Gy). Badacze zadali pytanie, czy w odniesieniu do przeżyć całkowitych, przeżyć bez wznowy biochemicznej, przeżyć swoistych dla raka stercza oraz wolnych od przerzutów odległych istnieje zysk wynikający z zastosowania wysokiej dawki radioterapii [19]. Do analizy końcowej w badaniu włączono 1449 chorych dla których okres obserwacji wynosił ponad 6 lat. Chorzy z potwierdzonym rakiem stercza z grupy pośredniego ryzyka progresji byli losowo przydzielani do ramienia ze standardową dawką RT - 70,2 Gy oraz ramienia badanego z wysoka dawką 79,2 Gy. W wywnikach uwagę zwraca relatywnie niski odsetek zgonów spowodowanych RS. Dominującą przyczyną zgonów po średnim okresie obserwacji w obu ramionach badanych były zgony sposowodwane przez przyczyny nie nowotworowe (ramię z niską dawką - 33\% vs. ramię z wysoką dawką - 34,4\%). Podczas gdy odsetek zgonów spowoodowanych progresją RS wynosił odpowiednio $5,6 \%$ vs. 3,5\%. Autorzy badania nie wykazali istotnego zysku w przeżyciach całkowitych czy też swoistych dla RS wynikającego z zastosowania wyższej dawki w grupie pośredniego ryzyka RS. Stwierdzono natomiast, że w tej grupie chorych eskalacja dawki przekłada się na istotnie statystycznie poprawę przeżyć bez wznowy biochemicznej. Biorąc powyższe pod uwagę można się pokusić o stwierdzenie, że w grupie chorych młodszych u których prognozujemy czas przeżycia sięgający przynajmniej powyżej 10 lat, a najlepiej ponad $15-20$ lat zastosowanie wyższej dawki może przełożyć się na zysk w przeżyciach całkowitych lub swoistych dla RS. Z tego też względu nasuwa sie bardzo ważna konkluzja praktyczna, że jednym z istotnych parametrów decydujących o wyborze strategi leczenia (dawki całkowitej) winien być stan ogólny chorego uwzględniajacy obecność schorzeń dodatkowych (Charlson comorbidity Index). Uwzględniając powyższe w doborze sposobu leczenia można przyjąć, że potencjalny kandydat do dawki wynoszącej około 70 Gy to chory powyżej 70 roku zycia z nowotworem o złośliwości < 7 (w skali Gleason) gdy w materiale jest do 50\% materiału zawierającego komórki rakowe, a PSA Velocity nie przekracza $2 \mathrm{ng} / \mathrm{ml} / \mathrm{rok}$. Należy też pamiętać, że w drzewie decyzyjnym nie powinno zabraknąć wiedzy o tym, że wraz ze wzrostem dawki niestety wzrasta ryzyko wystąpienia powikłań popromiennych.

Kolejny bardzo ważnym tematem naukowym jaki został podjęty podczas konferencji była jakości życia chorych z RS po przebytym leczeniu napromienianiem. Powszechnie akceptowany jest pogląd, że obok czasu przeżycia chorego bardzo istotna jest jakość życia po zakończonym leczeniu. W związku z tym, że czas przeżycia dla wszystkich metod napromieniania jest generalnie taki sam (IMRT, protonoterapia, brachyterapia LDR, brachyterapia HDR) kluczowym jest jak wygląda jakość życia u tych chorych po leczeniu. Generalnie problem oceny jakości życia w grupie chorych z RS jest nadal dużym wyzwaniem. Wynika to z tego, że nie ma jak dotychczas przeprowadzonych badań klinicznych porównujących bezpośrednio wspomniane wyżej techniki radioterapii. Chcąc wyciągnąć wnioski musimy oprzeć się na badaniach pośrednich. W podsumowaniu paneliści stwierdzili, że na chwilę obecną bardzo obiecująco wygląda radioterapia stosująca wysokie dawki frakcyjne. Niemniej dane do postawienia jednoznacznych wniosków mogą pochodzić jedynie z randomizowanych badań klinicznych porównujących te metody leczenia. 
W sesji edukacyjnej szczególną uwagę zwrócono na bardzo ważny problem jakim jest suboptymalne leczenie raka pęcherza moczowego. Wraz ze starzeniem się społeczeństwa i w związku z tym populacji chorych z rakiem pęcherza moczowego w wielu sytuacjach dochodzi do odstąpienia od radykalnego leczenia, a chodzi tutaj przede wszystkim o leczenie operacyjne. Podczas gdy radioterapia lub radiochemioterapia może być bardzo dobrą alternatywą do zabiegu operacyjnego. Podkreślenia wymaga także fakt, że objawy uboczne radioterapii czy radiochemioterapii są generalnie na zbliżonym poziomie jak po leczeniu operacyjnym. $Z$ tego też względu należy zwiększyć nacisk na interdyscyplinarne podejście do leczenia raka pęcherza moczowego w którym radioterapia jest nadal nie docenianą metodą leczenia. Zwłaszcza w grupie chorych u których występują obciążenia schorzeniami dodatkowymi.

\section{Piśmiennictwo / References}

[1] Krajowy Rejestr Nowotworów- Gruczoł krokowy. http://onkologia.org.pl/rak-gruczolu-krokowego/.

[2] Global Cancer Observatory, Globocan 2018; https://gco.iarc.fr/today/home.

[3] Ricco A, Manahan G, Lanciano R. The Comparison of Stereotactic Body Radiation Therapy and IntensityModulated Radiation Therapy for Prostate Cancer by NCCN Risk Groups. Front Oncol 2016; 6:184.

[4] Głowacki G, Bodusz D, Majewski W. Frakcjonowana radioterapia stereotaktyczna CyberKnifeTM chorych na raka gruczołu krokowego. Oncol 2012;62: 274-282.

[5] King C. Lehmann J. Adler J. Hai J. CyberKnife Radiotherapy for Localized Prostate Cancer: Rationale and Technical Feasibility. Technol Ca Res Treat 2003; 2: 25-29.

[6] Akaza H, Homma Y, Okada K i wsp: A prospective and randomized study of primary hormonal therapy for patients with localized or locally advanced prostate cancer unsuitable for radical prostatectomy: results of the 5-year follow-up. BJU Int 2003; 91: 33-6.

[7] Alcaraz A, Teillac P. Hormone therapy for prostate cancer: Guidelines versus Clinical Practice. Eur Urol 2006; 362-8.

[8] Amant RS, Dunscombe PB, Roberts GH. A cost - outcome analysis of long-term adjuvant goserelin in addition to radiotherapy for locally advanced prostate cancer. Urol Oncol 2003; 21: 171-7.

[9] Zapatero A, Guerrero A, Maldonado X i wsp. Late Radiation and Cardiovascular Adverse Effects After Androgen Deprivation and High-Dose Radiation Therapy in Prostate Cancer: Results From the DART 01/o5 Randomized Phase 3 Trial. Int J Radiat Oncol Biol Phys 2016;96:341-348.

[10] Bolla M, van Poppel H, Collette L i wsp. European Organization for Research and Treatment of Cancer. Postoperative radiotherapy after radical prostatectomy: a randomized controlled trial (EORTC trial 22911). Lancet 2005; 366: 572-78.

[11] Crook J, Ludgate C, Malone S i wsp. Report of a multicenter Canadian phase III randomized trial of 3 months vs. 8 months neoadjuvant androgen deprivation before standard-dose radiotherapy for clinically localized prostate cancer. Int J Radiat Oncol Biol Phys 2004; 60: 15-23.

[12] D’Amico AV, Manola J, Loffredo M i wsp. 6-month androgen suppression plus radiation therapy vs radiation therapy alone for patients with clinically localized prostate cancer: A randomized controlled trial. JAMA 2004; 292: 821-27.

[13] Dearnaley DP, Hall E, Lawrence D i wsp. Phase III pilot study of dose escalation using conformal radiotherapy in prostate cancer: PSA control and side effects. Br J Cancer 2005: 92: 488-98.

[14] Milecki P: Radioterapia skojarzona z hormonoterapią u chorych z rakiem gruczołu krokowego: nadal więcej pytań niż odpowiedzi. Przegl Lekarski 2005; 62: 1455-9.

[15] Sanguineti G, Marcerano M, Franzone P i wsp: Neoadjuvant androgen deprivation and prostate gland shrinkage during conformal radiotherapy. Radiother Oncol 2003; 66: 151-7.

[16] Valicenti KR, Winter K, Cox JD i wsp: RTOG 9406: is the addition of neoadjuvant hormonal therapy to dose-escalated $3 \mathrm{D}$ conformal radiation therapy for prostate cancer associated with treatment toxicity? Int J Radiat Oncol Biol Phys 2003;57:614-20.

[17] Samper PM, López Carrizosa C, Pérez Casas A i wsp. Impact of neoadjuvant hormonal therapy on dosevolume histograms in patients with localized prostate cancer under radical radiation therapy. Clin Trans Oncol 2006;8:599-605. 
[18] Ozyigit G, Akyol F, Onal C i wsp. Combined hormonotherapy and definitive radiation therapy in localized prostate adenocarcinoma. Inter Hematol and Oncol 2003;13:177-89.

[19] Michalski JM, Moughan J, Purdy J i wsp. Effect of Standard vs Dose-Escalated Radiation Therapy for Patients With Intermediate-Risk Prostate Cancer: The NRG Oncology RTOG 0126 Randomized Clinical Trial. JAMA Oncol 2018 14;4. 